\title{
Narrative Accounting Practices in Indonesia Companies
}

\author{
Inten Meutia ${ }^{1}$; Budiawan C. Putra ${ }^{2}$ \\ 1,2 Accounting Department, Faculty of Economics, Sriwijaya University \\ Jln. Srijaya Negara, Bukit Lama, Palembang 30139 Indonesia \\ 1inten26@yahoo.com; ²budiawancimarkoputra@yahoo.co.id
}

Received: $11^{\text {th }}$ January 2017/ Revised: $29^{\text {th }}$ March 2017/ Accepted: $30^{\text {th }}$ March 2017

How to Cite: Meutia, I., \& Putra, B. C. (2017). Narrative Accounting Practices in Indonesia Companies. Binus Business Review, 8(1), 77-83. http://dx.doi.org/10.21512/bbr.v8i1.1944

\begin{abstract}
This research aimed to reveal creative accounting practices in the form of narrative accounting occuring in companies in Indonesia. Using content analysis, this research analyzed the management discussion and analysis section in the annual report on the group of companies whose performance had increased and declined in several companies listed on the Indonesian Stock Exchange. This research finds that the narrative accounting practices are applied in these companies. The four methods of accounting narratives are found in both groups of companies. There are stressing the positive and downplaying the negative, baffling the readers, differential reporting, and attribution.
\end{abstract}

Keywords: creative accounting, narrative accounting, management discussion analysis, impression management

\section{INTRODUCTION}

Financial reporting is the most important instruments for all companies to disclose the performance and the company condition to investors, regulators, and employees (Elliott, 2006). Shah and Butt (2011) said that although the accounting system had already worked to create strict rules to make the information presented reasonable, there were still many areas that could be developed to give description based on the company interest to the financial reports users. The increasing of competition among companies makes the company attempt to make its financial results look good. It is known as creative accounting.

Creative accounting refers to the use of accounting information to influence reporting with remaining rule of law and accounting. Therefore, there is a tendency of companies to make reports that do not reflect the actual performance of the company. However it rather reflects what is desired by management to inform for the stakeholders. Moreover, Stolowy and Breton (2004) stated that many companies creatively manipulated financial data to get a good response from some stakeholders. Similarly, Maltby and Tsamenyi (2010) said that creative accounting was a part of the management by using accounting understanding and ability to create financial reports in accordance with the company interest (self-interest). Furthermore, Jones (2011) suggested that creative accounting was an action that had a purpose to intervene the financial reporting process in accordance with the company interest. One way of the management to show the company performance is through impression management to the stakeholders.

Impression management is a study in social psychology that studies how individuals present themselves in order to be well perceived by others (Hooghiemstra, 2000). In the context of the company's financial reporting, impression management is an effort to control and manipulate the impression conveyed to the accounting information users (Clatworthy \& Jones, 2006). The manager is supposed to use company reports as a means of impression management to strategically manipulate the perceptions and decisions of stakeholders (Yekini, Wisniewski, \& Millo, 2016). The concept of impression management applied in the context of the company report of the company is to analyze the efforts to influence the stakeholder perceptions toward the organization especifically financial performance as described by Clatworthy and Jones (2001; 2003; 2006) and Courtis (2004), and environment social performance (Hooghiemstra, 2000). 
Bolino, Kacmar, Turnley, and Gilstrap (2008) showed that managers used various impression management techniques in the narrative part of the annual report. One of the impression managements is a narrative accounting. In the United States and the United Kingdom, narrative accounting has been often used in the preparation of financial reports (Deloitte, 2010). Moreover, several researches have proven the benefits of narratives accounting. Clarkson and Kao (1999) documented that the narrative disclosure contained new information. Then, Breton and Taffler (2001) showed the narrative disclosure was useful for analysts. Meanwhile, Chng, Rodgers, Shih, and Song (2015) also showed that the narrative disclosure was made by manager for the annual report and the consequences of impression management.

In addition, Merkl-Davies and Brennan (2011) explained that there were four major perspectives about impression management. They were economics, psychology, sociology, and critical. Each perspective each had different dimensions related with the theory. Merkl-Davies and Brennan (2011) described that the economics and psychology perspectives focused on the efforts to manage the shareholders and stakeholders perceptions toward the company's financial performance. On the contrary, sociological perspective connected with the views and legitimacy of social and environmental responsibility of companies. Moreover, a critical perspective were power and focuses of management efforts to influence the stakeholders' perceptions on the influence and control of the company. These perspectives focus on the management's efforts to influence the perceptions of the parties concerning the companies on the environmental and social performance, and the adherence to norms and social rules.

Management Discussion and Analysis (MDA) has a close connection with creative accounting practices through the narrative accounting. Thus, narrative text is also a part that plays an important role for the company in forming a company impression. Frezatti, Carter, Barroso, and Carter (2014) said that MDA was a very important part of the annual report especially for those who analyzed the important or fundamental things including management and management style. However, some researchers actually find different things in the purposes of MDA. According to Deegan and Gordon, (1996), they stated there were a lot of weaknesses of the company covered or not disclosed in the MDA. Smith and Taffler (1992) also described that the company's poor financial performance had a difficult-to-understand language in reporting in MDA. Similarly, Morrow (2005) saw only $14 \%$ out of 3.317 company with negative cases coded as weaknesses in MDA. Clatworthy and Jones (2006) agreed that the manager was more selective in the use of narrative in MDA.

Narrative accounting practices at companies in Indonesia have not been proved by researchers so far. Therefore, this research aims to prove how narrative accounting practices in companies listed on the stock exchanges in Indonesia are. The results is expected to provide empirical evidence about the behavior of creative accounting in Indonesia in the form of narrative accounting.

\section{METHODS}

This research is an explorative study aiming to reveal the creative accounting behavior through narrative accounting of the companies in Indonesia. Moreover, the descriptive analysis is conducted by using a content analysis of annual reports from some company. The selected company has criteria which it has a trend of increase profit and decrease profit for three consecutive years. The companies with increasing profit trend profits which are chosen as samples are PT BFI Finance Indonesia Tbk, PT Ciputra Development Tbk, PT Elang Mahkota Teknologi Tbk, PT Tower Bersama Infrastructure Tbk, and PT Kimia Farma Tbk. Meanwhile companies with the decrease profit trend are PT XL Axiata Tbk, PT Indo Tambangraya Megah Tbk, PT Krakatau Steel Tbk, PT Sampoerna Agro Tbk, and PT Perusahaan Perkebunan London Sumatra Indonesia Tbk.

Moreover, content analysis will be done with MDA in the annual report by identifying a method commonly used in the accounting narrative. First, stress the positive and downplay the negative. This is emphasizing the positive things and covering the negative things. Companies which have a decrease profit trend tend to emphasize the positive things they have and cover the negative things happening in the companies. Second, baffle the readers. The companies with a decrease profit trend use bad reporting sentences and do not adequately reflect the figures in the financial reports that later would "baffle" the readers. Meanwhile, the companies with the increase profit trend use an easy language that is understood by the readers. Third, Differential Reporting. It is when companies with the increase profit trend report the results of past performance more clearly than the companies with the decrease profit trend. It focuses on the future in the reporting. Moreover, companies with increase profit trend use active sentences in reporting, while companies with decrease profit trend use passive sentences in reporting. Last, attribution. Companies with increase profit trend show that they are the cause of increasing in the companies' profits. Meanwhile, companies with decrease profit trend blame the external factors as the causes of the decrease in the company profit.

\section{RESULTS AND DISCUSSIONS}

The first result is about stressing the positive and downplaying the negative. It is normal for companies to continue accentuating the positive sides regarding the performance success that they have done throughout the year. However, when the companies experience the decrease in profits, they try 
to emphasize the successes achieved. Then, it can be said that they cover the company's problem occurred (Maltby \& Tsamenyi, 2010). This disclosure is found in the annual report of five companies which have a decrease profit trend. Firstly, it is in PT XLAxiata Tbk.

"We praise the Board of Directors and Staff for their achievements to generate a stable income Rp21,4 trillion, even though 2013 was a challenging year. We also praise them for increasing data revenues $16 \%$ from the previous year. This growth is the highest contributor to grow data revenue to XL income streams. This fact justifies and reinforces our determination to be leading players in the data business segment". (Annual Report of PT XL Axiata Tbk, 2013: 34).

The statement indicates that PT XL Axiata emphasizes the positive sides occurred which they have the increase in the revenue 16\% from 2012. However, in that year, they had experienced larger increase in company operating expenses and losses on foreign exchange differences. It made PT XL Axiata have decline in profit 63\% in 2013 from 2012. Secondly, it also happens in PT Indo Tambangraya Megah (ITM) Tbk.

"Despite many challenges, ITM is still able to maintain its efforts to increase sales of coal, from 27,2 million tons in 2012 to 29,1 million tons in 2013, indicating a growth of 7\%. This is the highest annual sales figure ever achieved". (Annual Report of PT Indo Tambangraya Megah Tbk, 2013: 34)

The statement describes that PT Indo Tambangraya Megah tries to show the success that they have achieved. Moreover, they even emphasize the phrase that it is the highest annual sales that they have ever achieved. On the other hand, the company does not explain that their profits have declined by $50 \%$ from the previous year. It has been declined from Rp432.043 billion in 2012 to Rp230.484 billion in 2013. Thirdly, in PT Krakatau Steel Tbk, there are some statements in the annual report.

"The growth of our business in 2012 was marked by the success of PT Meratus Jaya Iron \& Steel, one of the subsidiary Companies, it have begun to produce sponge iron with local raw material in November. Meanwhile, the construction project of PT Krakatau Posco, a joint venture with Posco, runs base on plan and has reached $69 \%$ so that the target to start operating in late 2013 might be achieved. The company has also been successfully to cooperate with forming a joint venture that will invest for development of automotive sector products and Bar \& Section products".

(Annual Report of PT Krakatau Steel Tbk, 2013: 33)
Based on financial reports in 2013, PT Krakatau Steel has a loss of Rp29 trillion. However, MDA in the company tries to highlight the positive side that they have achieved in that year. It is by showing the achievements of its subsidiaries and its joint venture. Fourthly, this situation also appears in PT Sampoerna Agro Tbk.

"Throughout the year 2012, due to the increase of market demand for Crude Palm Oil (CPO) as well as improvement of production capacity continuously, the Company has managed to achieve a satisfactory production growth. Total volume of FFB production increased by 7\%, from 1,61 million tons of production in 2011 to 1,72 million tons production in 2012".

(Annual Report of PT Sampoerna Agro Tbk, 2012: 36).

Judging from what have been disclosed in MDA in the year production growth of PT Sampoerna Agro, it has been increased by $7 \%$ from 2011 . The company even stresses the statement that it has satisfactory growth in production. However, when the company financial reports are analyzed, It is found out that the company sales has decreased by $5 \%$. Moreover, there is an increase in operating expenses which make the profit decline about $40 \%$ from 2011 . Fifthly, it is PT London Sumatra Plantation Indonesia Tbk.

"TBS core crops decreased 4.9\% from 1.314.823 tons to 1.250.375 tons in 2013, due to unfavorable weather conditions and TBS logistical conditions and certain social some areas. FFB purchased from external parties fell 29,7\% to 477.239 tons out of 679.149 tons, after the validity of TBS quality requirements was more stringent to increase the extraction rate. As a result, the production volume of $\mathrm{CPO}$ and palm kernel products declined respectively $11,5 \%$ and $12,4 \%$ to 396.493 tons and 94.444 tons. The palm oil and palm kernel extraction rates increased respectively $22,9 \%$ and $5,5 \%$ from $22,5 \%$ and $5,4 \% "$.

(Annual Report of PT London Sumatra Plantation Indonesia Tbk, 2013: 29)

Based on the statements delivered by PT London Sumatra Plantation Indonesia, the company do not cover the decrease in yield and CPO production and palm kernel despite its decrease profit trend. The company openly communicates what really has happened. It also reveals some positive things such as the increased of palm kernel extraction.

From the content analysis of MDA in the five companies, there is a similar tendency as found by Jones (2011), and Hussaney and Al-naijar (2011). Only one company does not conduct stress the positive, downplay the negative. In this case, the company with decrease profit trend tends to cover the decrease occurred by using positive sentences. Thus, the readers 
of annual report do not look at actual number of the financial reports. The reader will think the company has the best performance and profit but in fact it is not. This is related to the other factor which is called "baffle" the reader. For example, it happens in PT XL Axiata Tbk.

"XL closed the year 2012 with gross revenue growth reached 15\% Year-on-Year (YoY), with showing positive performance in all services compared to the previous year. This was primarily driven by the focus XL on the data: due to the support of large-scale investment in $3 G$ networks, revenue from data had grown $50 \%$ YoY and became the largest contributor to the growth, followed by conversation and SMS, which each grew 6\% YoY and 16\% YoY. Revenues from mobile telecommunications services, which was the foremost of XL business operations increased 17\% YoY to Rp19,6 trillion and contributed $92 \%$ toward total gross revenue. The shift in consumer behavior from the conversation and SMS towards data was reflected in the increase trend in revenue contribution from data toward total usage income, which rose from $15 \%$ to $20 \%$ within one year".

(Annual Report of PT XL Axiata, 2012: 68)

The sentences indicate that all aspects of the operation of PT XL Axiata has increased. Moreover, the readers can only conclude that PT XL Axiata has definitely significant increased profits. However, after seen the financial reports in the year PT XL Axiata, the reader will realize that it has decrease in net income about $6 \%$ from 2011.

The analysis about MDA content is related to the management effort to do what is known as baffle the readers. It reveals that the five companies with the lack of good management financial performance try to baffle the readers. Management tends to use technical language that is difficult to be understood by readers and direct them to capture highlighted things by management. The highlighted things might not necessarily show the actual performance of the company. This finding is consistent with the findings of Agyemang, Williams, and Yeon (2015), and Hussaney and Al-najjar (2011). The negative performance of the company as said by Beattie (2014) might pose a conflict of interest between managers and stakeholders. Managers are encouraged to manipulate the perceptions of outsiders on the financial performance to divert attention from the company's bad financial condition. Moreover, the companies with the increase profit trend focus more on the companies internal capabilities such as directors performance, and the internal capabilities to manage the company and establish relationships with outside parties. Meanwhile, the companies with a decrease profit trend focus on the market, the environment, world economic conditions, and exchange rate differences or other factors beyond the companies control.

The companies' activities cannot be separated from the profit and loss as well as an increase or decrease in profits. Companies with an increase profit trend make a statement that their performance causes increase in profit to happen. However, when the companies face losses or decrease in profits, the companies "blame" external factors causing the companies loss or decrease in profit (Jones, 2011).

When people look at each statement of managements in both groups of the company, it can be seen that when the sales, production or profit have increased, the management claims that their performances cause it. Meanwhile, when sales, production or profits are decreased, the management says that external factors such as the exchange rates and the bad weather modernization, the slow economic growth, the network, the exchange rate depreciation, the world economy condition, and the world financial crisis become the sources of the problems. From the five companies studied only one company does not blame the external parties of the company. That is PT London Sumatra Indonesia Plantation (Lonsum) Tbk. PT. Lonsum Tbk seems to admit the decrease in company performance without seeking external parties to blame. The result is suitable with the statement of Solomon, Solomon, Joseph, and Norton (2013). They revealed that through narrative texts companies actively tried to form a positive images and avoided the negative images. Moreover, the way that companies use to send messages through the annual report is a communication strategy. The different reporting analysis is shown in Table 1 between the companies with increase profit trend and decrease profit trend.

\section{CONCLUSIONS}

This research tries to find out how the accounting narrative practices of companies are in Indonesia as well as whether there are narrative differences between the two groups of companies. Based on the analysis it can be concluded into several things. Companies with a decrease profit trend stress positive things and achievements which they have achieved. On the other hand, they close the performance that they have experienced. Moreover, only one company does not use this method, which is PT London Sumatra Indonesia Plantation Tbk. It does not cover the loss of companies. It even clearly explains why there is a decline in profits occurred without emphasizing the positive things achieved. All companies with a decrease profit trend which are observed use positive phrases to "baffle" the readers.

All companies observed with the increase and decrease profit trend groups use the method of different reporting focus. Groups of the increase profit emphasize on the discussion about internal factor such as director performance, and the ability of internal parties to manage companies and relationships with 


\begin{abstract}
Companies with Increase Profit Trend
"In 2013, the Board completed a review of the Company's management conducted by the Board of Directors and was satisfied with the results obtained. Directors consistently proved their capabilities and skills in managing the company well and wisely, despite being in the midle of an economic slow condition, they were committed to achieve growth and at the same time good asset quality. Directors led the company to achieve profit growth before healthy Income Taxes despite many challenges faced in economic and industrial sectors throughout the year running and still be able to maintain a healthy asset quality with NPLs credit Managed 1,38\%".
\end{abstract}

(Annual Report of PT BFI Finance Indonesia, 2013: 19)

"Throughout 2013, the Board conducted supervising function assisted by the Committee of Audit based on the principles of Good Corporate Governance (GCG) '”. (Annual Report of PT Ciputra Development Tbk, 2013:21)

"In 2012, once again it was a glorious year for Emtek. Group strategy focused on maintaining a conservative balance sheet, enabling us to get the opportunity when it arose, and in a relatively short time. We were able to maintain revenue and high profitability of growth organically".

(Annual Report of PT Elang Mahkota Teknology Tbk, 2012: 15)

"We focused on the development and implementation of policies and business practices in the efforts to maximize values for shareholder and customer satisfaction. Operationally, we had integrated all of a standardized management system that had been acquired into a unified management system through the implementation of a publicly Available Specification 99 (PAS 99). Through the implementation of PAS 99 system in management (ISO 9001: 2008 Quality Management, ISO 14001 Environmental Management, OHSAS 18001:2007 Occupational Health and Safety Management and ISO 26000 Social Responsibility) were integrated into an entity that would enable control and supervision to the business process quality applied. We also adhered to good corporate governance, placed the important values on the principles of fairness, transparency, accountability and responsibility ".

(Annual Report of PT Tower Bersama Infrastructur Tbk, 2013: 31)

"In 2013, the Company still continued to run company transformation consistently transformation, which this year was a stage of the Managing Operational Excellence. Things that became obstacles to the progress of the Company's performance, became a particular concern of company management to overcome these obstacles, the Company Managements actively looked for solutions and new breakthroughs through forums of Management Review which was routinely carried out by involving all Divisions and Work Unit ".

(Annual report of PT Kimia Farma Tbk, 2013:42)

\section{Companies with Decrease Profit Trend}

"We had seen interests in Indonesia would continue to grow in 2013. Consumers more integrated data related application into their lives and activities. In line with the growth of the middle class purchasing, purchasing power of mobile devices and mobile device-related data services also continued to grow well. Consumers also continued to shift their communication behavior of Voice and SMS to Mobile Data and Digital Services".

(Annual Report of PT XL Axiata Tbk, 2013: 39)

"In the unstable global economic situation, especially in the second half of 2013, particularly due to the authority taken by the US central bank to reduce the stimulus, the situation in the commodity sector did not look good. Coal price index fell by an average 16\% from 2012 to 2013, in the increasing imports from China, a coal consumer in the world and one of the Important ITM".

(Annual Report PT Indo Tambangraya Megah Tbk, 2013:17)

"Although global economic growth in 2012 was not as good as predicted, due to the crisis in Europe, economic growth in Indonesia was still good even though it was slightly lower than the initial estimate".

(Annual Report of PT Krakatau Steel Tbk 2013: 32)

"We believed that the rubber could stem the palm oil price movements over time. Although there was substitution product to natural rubber, synthetic rubber but overall could not replace the natural rubber. In addition, synthetic rubber was a downstream product of petroleum So when the oil price increased, the synthetic rubber price would also increase so that employers would go to natural rubber".

(Annual Report of PT Sampoerna Agro Tbk, 2013:35)

"Throughout the year 2013, the global commodity markets still experienced low commodity prices due to the falling demand as the continue of the slow global economic. In addition, the Government's decision to raise the minimum wage had led to increase production costs for plantation companies operating in Indonesia". (Annual Report of PT London Sumatra Indonesia Plantation, 2013: 28) 
outside parties. Meanwhile, groups of the decrease profit focus on the market, the environment, world economic conditions and exchange rate differences or other factors beyond the companies ' control.

Furthermore, groups of the increase profit trend claim that company performance (internal parties) leads to an increase in companies' profits. On the other hand, groups of the decrease profit trend "blame" external factors that cause decrease in companies' profits. The company that does not use this method is PT London Sumatra Indonesia Plantation. Thus, it can be said that the creative accounting practices in the form of narrative accounting become one of efforts done by management to give the impression to readers. It is by using the annual report which is suitable with management interests.

This research attempts to uncover whether creative accounting practices in form of accounting narrative are also conducted by the companies listed in the Indonesia Stock Exchange. This research obtains an illustration of creative accounting practices through the accounting narrative occurred in several companies in Indonesia. However, a further research is needed to give the better insight whether the practices are conducted by many companies or not. It is because this research only uses data from ten companies. Moreover, in-depth research can also be conducted to understand and explain why management does or does not do it. This can be done by using the ethics and religion approaches that the creative accounting has close linkages with moral hazard.

\section{REFERENCES}

Agyemang, K. J., Williams, A. S., \& Kim, D. Y. (2015). "Scandalous!": Reputation, impression management, and Employee Assistance Programs (EAPs) in the NBA. Sport Management Review, 18(4), 609-617.

Beattie, V. (2014). Accounting narratives and the narrative turn in accounting research: Issues, theory, methodology, methods and a research framework. British Accounting Review, 46(2), 111-134. http:// doi.org/10.1016/j.bar.2014.05.001

Bolino, M. C., Kacmar, K. M., Turnley, W. H., \& Gilstrap, J. B. (2008). A multi-level review of impression management motives and behaviors. Journal of Management, 34(6), 1080-1109. http://doi. org $/ 10.1177 / 0149206308324325$

Breton, G., \& Taffler, R. J. (2001). Accounting information and analyst stock recommendation decisions: A content analysis approach. Accounting and Business Research, 31(2), 91-101. http://doi.org/10.1080/000 14788.2001.9729604

Chng, D. H. M., Rodgers, M. S., Shih, E., \& Song, X. (2015). Leaders' impression management during organizational decline: The roles of publicity, image concerns, and incentive compensation. The Leadership Quarterly, 26(2), 270-285. http://doi. org/10.1016/j.leaqua.2014.12.003

Clarkson, P. M., \& Kao, J. L. (1999). Evidence that
Management Discussion and Analysis (MD\&A) is a part of a firm's overall disclosure package. Contemporary Accounting Research, 16(1), 111-134. http://doi.org/10.1111/j.1911-3846.1999.tb00576.x

Clatworthy, M., \& Jones, M. J. (2001). The effect of thematic structure on the variability of annual report readability. Accounting, Auditing \& Accountability Journal, 14(3), 311-326. http://doi. org/10.1108/09513570110399890

Clatworthy, M. A., \& Jones, M. J. (2003). Financial reporting of good and bad news: Evidence from accounting narratives. Accounting and Business Research, 33(3), 171-185. http://doi.org/10.1080/00 014788.2003.9729645

Clatworthy, M.A., \& Jones, M. J. (2006). Differential patterns of textual characteristics and company performance in the chairman's statement. Accounting, Auditing \& Accountability Journal, 19(4), 493-511. http://doi. org/10.1108/09513570610679100

Courtis, J. K. (2004). Corporate report obfuscation: Artefact or phenomenon? British Accounting Review, 36(3), 291-312. http://doi.org/10.1016/j.bar.2004.03.005

Deegan, C., \& Gordon, B. (1996). A study of the environmental disclosure practices of Australian corporations. Accounting and Business Research, 26(3), 187-199. http://doi.org/10.1080/00014788.1 996.9729510

Deloitte. (2010). Swimming in words: Surveying narrative reporting in annual reports. Retrieved from www. iasplus.com/en/binary/uk/1010ukswimminginwords. pdfln

Elliott, W. B. (2006). Are investors influenced by pro forma emphasis and reconciliations in earnings announcements? The Accounting Review, 81(1), 113-133.

Frezatti, F., B. Carter, D., \& FG Barroso, M. (2014). Accounting without accounting: Informational proxies and the construction of organisational discourses. Accounting, Auditing \& Accountability Journal, 27(3), 426-464.

Hooghiemstra, R. (2000). Corporate communication and impression management-new perspectives why companies engage in corporate social reporting. Journal of Business Ethics, 28(1/2), 55-68. http:// doi.org/10.1023/A:1006400707757

Hussainey, K., \& Al-Najjar, B. (2011). Future-oriented narrative reporting: determinants and use. Journal of Applied Accounting Research, 12(2), 123-138.

Jones, M. J. (2011). The nature, use, and impression management of graphs in social and environmental accounting. Accounting Forum, 35(2), 75-89. http:// doi.org/10.1016/j.accfor.2011.03.002

Maltby, J., \& Tsamenyi, M. (2010). Critical perspectives on accounting narrative accounting disclosure : Its role in the gold mining industry on the Gold Coast 19001949. Critical Perspectives on Accounting, 21(5), 390-401. http://doi.org/10.1016/j.cpa.2010.03.001

Marder, B., Slade, E., Houghton, D., \& Archer-Brown, C. (2016). "I like them, but won't 'like'them": An examination of impression management associated with visible political party affiliation on Facebook. 
Computers in Human Behavior, 61, 280-287. http:// doi.org/10.1016/j.chb.2016.03.047

Merkl-Davies, D., Brennan, N., \& Vourvachis, P. (2011). Text analysis methodologies in corporate narrative reporting research. In $23^{\text {rd }}$ CSEAR International Colloquium.

Morrow, S. (2005). The bussiness of football: Image management in narrative communication. The British Accounting Review, 38(1), 125-127. http:// doi.org/10.1016/j.bar.2005.11.002

PT BFI Finance Indonesia Tbk. (2013). Annual report of PT BFI Finance Indonesia Tbk. Retrieved from https:// www.bfi.co.id/en/investor-relations/annual-report

PT Ciputra Development Tbk. (2013). Annual report of PT Ciputra Development Tbk. Retrieved from http:// www.ciputradevelopment.com/investor-relation/ annual-reports

PT Elang Mahkota Teknology Tbk. (2012). Annual report of PT Elang Mahkota Teknology Tbk. Retrieved from http:/www.emtek.co.id/annual-report

PT Indo Tambangraya Megah Tbk. (2013). Annual report PT Indo Tambangraya Megah Tbk. Retrieved from http://www.itmg.co.id/id/investor-relation/annualreport

PT Kimia Farma Tbk. (2013). Annual report of PT Kimia Farma Tbk. Retrieved from http://www. kimiafarma. co.id/investor/laporan-tahunan.html

PT Krakatau Steel Tbk. (2013). Annual report of PT Krakatau Steel Tbk. Retrieved from http://www. krakatausteel.com $/=$ content\&cid $=129$

PT London Sumatra Indonesia Plantation Tbk. (2013). Annual report of PT London Sumatra Indonesia Plantation Tbk. Retrieved from http://www. londonsumatra.com/contentDownload.aspx?mid=47

PT Sampoerna Agro Tbk. (2012). Annual report of PT Sampoerna Agro Tbk. Retrieved from http://www.
Sampoerna.com/id_id/investor_information/ disclosures_and reports/pages/annual_reports.aspx

PT Sampoerna Agro Tbk. (2013). Annual report of PT Sampoerna Agro Tbk. Retrieved from http:// www.sampoerna.com/id_id/investor_information/ disclosures_and_reports/pages/annual_reports.aspx

PT Tower Bersama Infrastructur Tbk. (2013). Annual report of PT Tower Bersama Infrastructur Tbk. Retrieved fromhttp://www.tower-bersama.comannual-reports

PT XL Axiata Tbk. (2012). Annual report of PT XL Axiata Tbk. Retrieved from http:/www.xl.co.id/ corporate/ en/investor/information/ annual-report

PT XL Axiata Tbk. (2013). Annual report of PT XL Axiata Tbk. Retrieved from http://www.xl.co.id/corporate/ en/investor/information/annual-report

Shah, A., \& Butt, S. (2011). Creative accounting: A tool to help companies in a crisis or a practice to land them into crises. International Conference on Business and Economics Research, 16, 96-102.

Smith, M., \& Taffler, R. (1992). The chairman's statement and corporate financial performance. Accounting \& Finance, 32(2), 75-90.

Solomon, J. F., Solomon, A., Joseph, N. L., \& Norton, S. D. (2013). Accounting, organizations and society impression management, myth creation and fabrication in private social and environmental reporting: Insights from Erving Goffman. Accounting, Organizations and Society, 38(3), 195213. http://doi.org/10.1016/j.aos.2013.01.001

Stolowy, Hervé, \& Breton, G. (2004).Accounts manipulation: A literature review and proposed conceptual framework. Review of Accounting and Finance, 3(1), 5-92. http://doi.org/10.1108\%2Feb043395

Yekini, L. S., Wisniewski, T. P., \& Millo, Y. (2016). Market reaction to the positiveness of annual report narratives. The British Accounting Review, 48(4), 415-430. http://doi.org/10.1016/j.bar.2015.12.001 